SIMONA GROSSI* \& ALLAN IDES ${ }^{\dagger}$

\title{
The Modern Law of Class Actions and Due Process
}

Introduction 53

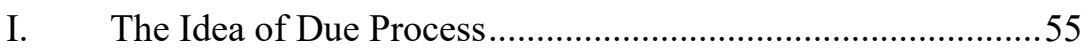

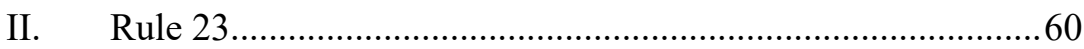

A. The Original Rule ........................................................60

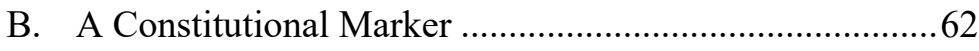

C. The Current Rule-1966 and Beyond...............................64

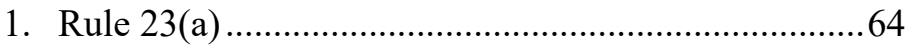

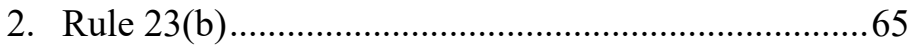

3. The Rule in the Court's Jurisprudence .......................72

4. Amchem Products, Inc. v. Windsor .............................72

5. Ortiz v. Fibreboard Corp. .......................................... 77

6. Wal-Mart Stores, Inc. v. Dukes ................................. 82

7. Amgen Inc. v. Connecticut Retirement Plans and

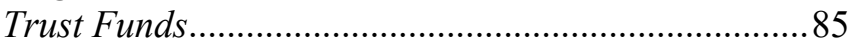

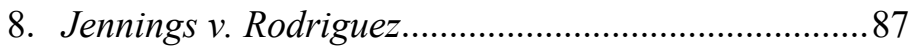

9. Nutraceutical Corp. v. Lambert ...............................93

10. China Agritech, Inc. v. Resh.....................................96

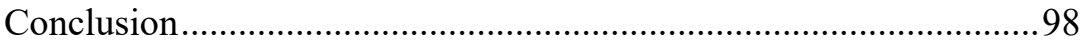

\section{INTRODUCTION}

ny examination of the law of class actions must begin with the

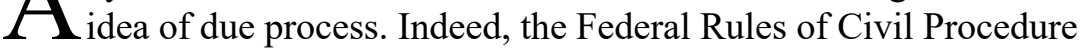
are collectively built on this idea as explicitly stated in Rule 1: "These rules ... should be construed, administered, and employed by the court

\footnotetext{
* Professor of Law \& Theodore Bruinsma Fellow, Loyola Law School Los Angeles.
}

$\dagger$ Christopher N. May Professor of Law, Loyola Law School Los Angeles. 
and the parties to secure the just, speedy, and inexpensive determination of every action and proceeding." Rule 23 is and should be viewed from that same due process perspective. So we begin with a brief consideration of the idea and the law of due process.

The law of due process is the product of judicial decisions enforcing the texts of the Fifth and Fourteenth Amendment Due Process Clauses to the United States Constitution as limitations on government action. ${ }^{2}$ The lodestar opinions are Mullane v. Central Hanover Trust ${ }^{3}$ and Mathews v. Eldridge, ${ }^{4}$ which set forth the foundational ideas and contours of due process. Generally stated, the law of due process sets flexible baseline standards of government obligation whenever a person's right to life, liberty, or property is put at risk by government action. The presumption underlying due process - premised on the perceived effectiveness of the adversarial system - is that no person should suffer a deprivation of those protected interests in the absence of timely notice and an opportunity to be heard. Deviations from this presumptive norm, subject to certain limits and safeguards, are dependent on a consideration of the nature and scope of the deprivation, the legitimate interests of the government, and the truth-seeking effectiveness of the procedure offered, including any reasonably available alternatives.

But the idea of due process is much broader than this judicially imposed limitation on power. It is premised on a profound but tempered commitment to the rule of law, reasonably and fairly applied, and a concomitant distrust of the exercise of arbitrary power. It also bespeaks an equitable and sensible flexibility and places its faith in the adversarial system's capacity to approximate the truth and deliver justice. Its hallmarks are reasonableness, impartiality, and respect for both the rights of the individual and the legitimate needs of the community. One might say that the aim of due process is justice reasonably, fairly, and efficiently pursued. ${ }^{5}$

Of course, reasonable minds can and will differ as to what constitutes due process, both philosophically and as a matter of law. The lens of due process will not lead to an obvious solution in any but the most obvious cases. But that lens should provide a perspective

\footnotetext{
1 FED. R. CIV. P. 1.

2 See generally Simona Grossi, Procedural Due Process, 13 Seton Hall CIR. ReV. 155 (2017).

3339 U.S. 306 (1950).

4424 U.S. 319 (1976).

5 See id.
} 
through which to engage the debate on the value and effectiveness of any particular procedural rule or standard. It will, at the very least, point to the right questions and, eventually, to the solutions that are optimal for the system and for the just resolution of individual claims of right that the system is there to provide.

This idea of due process permeates (or should permeate) our civil justice system. Thus, while not every nook and cranny of procedural law is itself required by the law of due process, which establishes only the floor below which the law cannot operate, the vast body of procedural law should be interpreted and applied through the much more inclusive idea of due process. This idea may be thought of as a type of high vaulted ceiling that reaches skyward, toward the ideal of true justice, but with its feet planted solidly on a foundation of reasonable standards and realistic expectations. That is the theme of this Article as applied in the particular context of class actions.

The law of class actions - which focuses largely on Federal Rule of Civil Procedure $23^{6}$ and judicial interpretations of that rule-is necessarily bounded by the law of due process. But it was also conceived within the more inclusive idea of due process. Rule 23 should, accordingly, be interpreted with the idea of due process as its driving force. ${ }^{7}$ This Article begins with an examination of the fundamental principles of due process and shows how those principles have permeated our system of justice and, more particularly, the Federal Rules of Civil Procedure. We then proceed to examine the text of Rule 23 from its original form to its most current iteration, using the idea of due process as our interpretive guide. Finally, we will examine several Supreme Court decisions interpreting Rule 23. Our goal here is to study those decisions from the perspective of due process.

\section{I}

\section{THE IDEA OF DUE PROCESS}

The idea of due process, like the law of due process, can be traced to a vast array of ancient texts and traditions, ${ }^{8}$ but a critical pivot point is certainly the Magna Carta. By signing that charter in 1215 at the behest of a group of rebellious barons, King John acceded to the basic

\footnotetext{
6 FED. R. CIV. P. 23.

7 See Simona Grossi, Frontloading, Class Actions, and a Proposal for a New Rule 23, 21 LEWIS \& CLARK L. REV. 921 (2017).

8 See, e.g., Deuteronomy 19:15-20, Proverbs 31:9, Psalms 106:3, Romans 4:15, 5:13; ARistotle, Politics (C.D.C. Reeve trans., 1998) (384-323 B.C.); Plato, The RePubliC (B. Jowett trans., 2003) (381 B.C.).
} 
rule-of-law proposition that no person-no matter how exalted-was above the law, and that all free persons were entitled to the evenhanded protection of the law.

The Magna Carta was reaffirmed, revised, and expanded in 1227 during the reign of Henry III. The new charter provided,

No Freeman shall be taken or imprisoned, or be disseised of his Freehold, or Liberties, or free Customs, or be outlawed, or exiled, or any other wise destroyed; nor will We not pass upon him, nor condemn him, but by lawful judgment of his Peers, or by the Law of the Land. We will sell to no man, we will not deny or defer to any man either Justice or Right. ${ }^{9}$

The word "Freeman" applied broadly, including both sexes and serfs (with some limits). In subsequent acts of Parliament, the phrase "law of the land" was replaced with "due process of law." This alteration of text was meant to endorse the same rule-of-law principle established in the Magna Carta and represent the same quest for a just system of laws. ${ }^{10}$ As Sir Edward Coke explained in his explication of the revised charter,

No man shall be disseised, that is, put out of seison, or dispossessed of his free-hold (that is) lands, or livelihood, or of his liberties, or free customes, that is, of such franchises, and freedomes, and free customes, as belong to him by his free birth-right, unlesse it be by the lawfull judgement, that is, verdict of his equals (that is, of men of his own condition) or by the Law of the Land (that is, to speak it once for all) by the due course, and processe of Law. ${ }^{11}$

Neither the Magna Carta nor subsequent acts of Parliament defined the ultimate scope of due process (or justice) or set the permanent metes and bounds of those principles. However, they established the principle that no free person could be deprived of his or her basic rights in the absence of the due operation of established law and provided that a

9 II The Selected Writings and Speeches of SiR EDWARd CoKe 848 (Steve Shepard ed., 2003) (1606) [hereinafter SIR EDWARD COKE].

10 Murray's Lessee v. Hoboken Land \& Improvement Co., 59 U.S. (18 How.) 272, 276 (1855); see also JOSEPH STORY, COMMENTARIES ON THE CONSTITUTION OF THE UNITED STATES, 663 (1833) ("Lord Coke says, that these latter words, per legem terrae (by the law of the land,) mean by due process of law, that is, without due presentment or indictment, and being brought in to answer thereto by due process of the common law."). It is true that the phrase "due process of law" technically referred to writs and forms of the law (process), but writs and forms defined the content of the law of the land. $C f$. RODNEY L. MOTT, DUE PROCESS OF LAW 87-95 (1973) (emphasizing the "process" aspect of the phrase, but failing to see the relationship between process and substantive law).

11 SIR EDWARD COKE, supra note 9, at 849. 
carefully wrought system of rights and obligations could become the vehicle for seeking some semblance of justice.

Over the next several centuries, the system of common law pleading emerged and evolved into a highly formalistic method of civil dispute resolution. ${ }^{12}$ Under this regime, in the specific context of civil litigation, the idea of due process was embodied largely in the forms of action and in the attendant system of issue pleading. ${ }^{13}$ But the common law system became increasingly formalistic and, as a result, occasionally elevated the rule of law-both procedural and substantive - above its rightful station. ${ }^{14}$ Of course, the forms were not dictated by due process and, judged by today's standards, the serpentine processes of issue pleading would likely fall short of our due process ideals. Yet the system itself reflected, albeit imperfectly, the idea of due process to the extent that it precluded (or was perceived to preclude) arbitrary deprivations of protected rights. It adhered to the rule of law and permitted impositions on individual rights only in accord with the established processes of that law.

The rule-of-law principle established in the Magna Carta was a response to unaccountable despotism. But it was not (nor should it be seen as) an invitation to elevate the law above reason and justice, which is to say above the idea of due process. Rather, the rule-of-law principle is meant to create a path to justice. A system of oppressive or arcane laws, whether they be procedural or substantive, can be as despotic as an unaccountable tyrant. Ideally, a system of laws should operate as one component of a larger system of justice - one that is neither despotic nor subject to any form of permanence or rule-of-law orthodoxy. To do justice, the law needs some breathing space. This is the role of equity.

Equity, which arose in the fifteenth century as an alternative method of dispute resolution, was an implicit due process critique of the then extant common law system. Where the common law demanded strict adherence to formality, equity offered a more open-textured alternative. Where the common law gave no remedy for an apparent injustice, the Chancellor could devise one. In short, where the common law was frozen and could not provide justice, equity would do so by

\footnotetext{
12 For a brief overview of the common law system, see ALLAN IDES \& CHRISTOPHER N. MAY, Civil Procedure: CASES AND PROBLEMS 561-70 (4th ed. 2012).

13 See SIR EDWARD COKE, supra note 9, at 848-73.

14 For a valuable historical overview of the common law system, see I DAVID DUDLEY Field, SPEEChes, ARguments, AND Miscellaneous PAPERS OF DAVID DudLEy Field 233-36 (A.P. Sprague ed., 1884).
} 
moving forward - perhaps only in small, carefully measured stepsbut forward nonetheless.

Of course, equity had its flaws. As with all systems, equity became barnacled with technicalities. But equity, whatever its ultimate strengths and weaknesses, grew naturally out of the idea of due process by aiming to do justice when existing procedures were incapable of doing so. We typically think of the equitable principle of "no adequate remedy at law" as a limit on access to equity. However, "no adequate remedy at law" is better seen as an invitation to allow justice when the law has failed to do so.

In America, the nineteenth-century movement to reform code pleading - inspired largely by the work of David Dudley Field — was undoubtedly premised on a widely shared perception that the AngloAmerican legal system had become incapable of delivering the promise of due process. In Field's words, "[A]t this moment we are in a state in which justice is virtually denied to great numbers of people. Speedy justice is a thing unknown; and any justice, without delays almost ruinous, is most rare." 15 The civil litigation system was not, in other words, a system through which justice could be reasonably, fairly, and efficiently achieved. Field's goal, which he pursued with energy, passion, and some degree of success, was to simplify procedure by creating an accessible, unitary system of justice premised on a scientific examination of existing procedures and the adoption of what he described as a realistic, natural system shorn of unnecessary complexity. ${ }^{16}$ Thus, in contrast to the arcane rules of common law pleading where "[j] ustice is entangled in the net of forms," " under the Field Code, "the pleadings would naturally fall into a plain, short statement by each party, of his own case." 18

15 Id. at 226, 229 ("natural scheme of legal procedure"). Field may have been a visionary, but his vision was premised on a realistic appraisal of the flaws in the system under which he labored and the possibilities of the new: "There will never be an administration of the law without delay and without expense. The question is really one of degree. How good can we make that which cannot be perfect? How much of the delay, how much of the expense, and how much of the uncertainty can we remove?" Id. at 225.

16 Id.

17 Id. at 228 .

18 Id. at 230; see also id. at 233 ("This form of pleading is natural. The plaintiff states his cause of action. The defendant gives his answer to it."); $i d$. at 240 ("Let the plaintiff set forth his cause of action in his complaint briefly, in ordinary language, and without repetition; and let the defendant make his answer in the same way. Let each party verify his allegation by making oath that he believes it to be true. The complaint will then acquaint the defendant with the real charge, while the answer will inform the plaintiff of the real defense. The disputed facts will be sifted from the undisputed, and the parties will go to trial knowing 
As Field himself recognized, however, the practice of law is highly resistant to change. ${ }^{19}$ The codes fell victim to the lingering, formalistic habits of lawyers and judges trained in the common law. This was particularly evident in the context of pleadings, where Field's vision of a "plain, short statement" devolved into the still-elusive distinctions drawn between ultimate facts, evidentiary facts, and conclusions of law. ${ }^{20}$ Moreover, the code phrase "cause of action" became mired in the law of primary rights and in the imposition of formal rules that treated the pleadings as an end in themselves. ${ }^{21}$ Thus, Field's goal of creating a pragmatic procedural system that advanced the idea of due process was stymied (or at least hobbled) by the siren song of formalism. $^{22}$

Reformers of the twentieth century, chief among them being Charles E. Clark, sought to return code pleading to its core project of creating an elegant procedural system premised on natural lawyering and judging. Theirs was a due process mission, for they sought to create a system of procedure under which justice could reasonably and realistically be pursued. ${ }^{23}$ That system would be a means to justice, not an end in itself. The monument to their project was the adoption of the Federal Rules of Civil Procedure (the Rules) in 1938. The Rules were simple, pragmatic, and designed to work. They borrowed from Fieldhis "plain, short statement" became Rule 8(a)(2)'s "short and plain statement" - and applied his philosophy to their perception of the then current best practices. ${ }^{24}$ Rule 1 of the new Federal Rules required that the Rules "be construed to secure the just, speedy, and inexpensive determination of every action." ${ }^{25}$ In other words, the Rules were to be

what they have to answer. The plaintiff will state his case as he believes it, and as he expects to prove it. The defendant, on his part, will set forth what he believes and expects to establish, and he need set forth no more.").

$19 \mathrm{Id}$. at 225.

20 See Charles E. Clark, Handbook of the Law of Code Pleading 231 (2d ed. 1947). The State of California adheres to the code pleading model. As to the "still elusive" nature of the distinction, the current version of one of California's leading practice manuals - Continuing Education of the Bar-offers the following observation: "The distinctions between ultimate facts, conclusions, and evidentiary facts, however, are not always easy to draw and often are a matter of degree." CONTINUING EDUC. OF THE BAR, CALIFornia Civil Procedure Before TRIAL $§ 15.26$ (2018).

21 Charles E. Clark, The Code Cause of Action, 33 YALE L.J. 817, 820-22 (1924).

22 Id. at $819-20$.

23 Id. at $823-24$.

24 FED. R. CIV. P. 8(a)(2).

25 SenAte, Rules of Civil Procedure for the District Courts of THE UNited STATES WITH INDEX AND NOTES, S. Doc. No. 101, at 1 (1st Sess. 1939). 
interpreted and applied to advance the idea and ideals of due process: justice reasonably, fairly, and efficiently pursued.

II

RULE 23

\section{A. The Original Rule}

The Rules provided a pragmatic and liberal approach to joinder of claims and parties, including party joinder through the device of class actions when the usual forms of joinder were otherwise inadequate. ${ }^{26}$ The text of the original rule, which relied substantially on former Equity Rule $38,{ }^{27}$ was succinct:

Rule 23. Class Actions.

(a) REPRESENTATION. If persons constituting a class are so numerous as to make it impracticable to bring them all before the court, such of them, one or more, as will fairly insure the adequate representation of all may, on behalf of all, sue or be sued, when the character of the right sought to be enforced for or against the class is

(1) joint, or common, or secondary in the sense that the owner of a primary right refuses to enforce that right and a member of the class thereby becomes entitled to enforce it;

(2) several, and the object of the action is the adjudication of claims which do or may affect specific property involved in the action; or

(3) several, and there is a common question of law or fact affecting the several rights and a common relief is sought.

-..

(c) Dismissal or COMPROMise. A class action shall not be dismissed or compromised without the approval of the court. If the right sought to be enforced is one defined in paragraph (1) of subdivision (a) of this rule notice of the proposed dismissal or compromise shall be given to all members of the class in such manner as the court directs. If the right is one defined in paragraphs (2) or (3) of subdivision (a) notice shall be given only if the court requires it. ${ }^{28}$

\footnotetext{
26 See id. at Rules 13-14, 18-25, 18-20, 24-30.

27 Id. at 240.

28 Id. at $27-28$.
} 
The Advisory Committee offered three illustrations of subsection (a)(1): (1) "actions brought by or against representatives of an unincorporated association;" (2) actions "to enforce rights held in common by policyholders against the corporate issuer of the policies;" and (3) "suit[s] by stockholders to enforce a corporate right." 29 To illustrate subsection (a)(2), the notes mentioned "[a] creditor's action for liquidation or reorganization of a corporation." ${ }^{30}$ Finally, with respect to subsection (a)(3), the notes cited several cases in which a class representative sought injunctive relief on a question common to the class. ${ }^{31}$ Ultimately, the actions mentioned in the notes were not particularly innovative because each was premised on previously recognized equitable practices in state and federal courts. ${ }^{32}$

One aspect of original Rule 23 might strike a modern reader as curious. While Rule 23(c) required notice of any proposed dismissal or compromise in an action filed under (a)(1), "neither rule (a)(2) nor (a)(3) required such notice." This might appear anomalous as to (a)(3), since that section seems to be a more inclusive category and one likely to trigger the due process rights of potential class members. The explanation for this lacuna is, however, simple: judgments in (a)(3) actions were binding only on class members who chose to intervene. In other words, (a)(3) actions were not, in fact, representative suits as that phrase is now commonly understood. ${ }^{33}$ Thus, the actual scope of the original class action rule was quite narrow and far from visionary. And although the original rule purported to apply to both legal and equitable proceedings, the recognized types of class actions seemed to fall most naturally into the equitable category.

$29 I d$. at 241 (alteration in original).

$30 \mathrm{Id}$. at 242 (alteration in original).

31 See id. at 241 .

32 See William Wirt Blume, The "Commons Questions" Principle in the Code Provision for Representative Suits, 30 MICH. L. REV. 878 (1932).

33 As explained in the Advisory Committee Notes to the 1966 Amendment of Rule 23:

The "spurious" action envisaged by original Rule 23 was in any event an anomaly because, although denominated a "class" action and pleaded as such, it was supposed not to adjudicate the rights or liabilities of any person not a party. It was believed to be an advantage of the "spurious" category that it would invite decisions that a member of the "class" could, like a member of the class in a "true" or "hybrid" action, intervene on an ancillary basis without being required to show an independent basis of Federal jurisdiction, and have the benefit of the date of the commencement of the action for purposes of the statute of limitations.

Proposed Rules of Civil Procedure for the United States District Courts, 39 F.R.D. 69, 99 (1966) [hereinafter 1966 Amendments]. 
In operation, Rule 23 proved to be unsatisfactory and of limited utility in a rapidly morphing world of litigation practices. The Rule was, as Clark had predicted, too "restrictive." 34 Other committee members agreed with him and had endorsed a more flexible approach to the rule. ${ }^{35}$ The full committee, however, opted for a less promising, equity-driven text. By doing so, the drafters locked class actions into narrow, preexisting categories. Those three categories - denominated respectively as "true," "hybrid," and "spurious"-proved difficult to define and unpredictable in application. ${ }^{36}$ Moreover, rather than promoting flexibility, many courts adhered to the familiar patterns that predated the rules, thus freezing class actions in their place.

The Advisory Committee Notes to the 1966 amendments to the Federal Rules detail the perceived deficiencies of the original rule. ${ }^{37} \mathrm{In}$ a sense, the original Rule 23 operated as a due process promise to be fleshed out at some future date. But in practice, the Rule did not deliver on that promise.

\section{B. A Constitutional Marker}

The Supreme Court's landmark decision in Hansberry v. Lee, although not premised on Rule 23, brought the idea and law of due process to the forefront of the jurisprudence of representative suits. ${ }^{38}$ The plaintiffs in that case sought to enforce a racially restrictive covenant against an African American buyer and the seller of a home that was arguably subject to the covenant. ${ }^{39}$ The defendants asserted that the covenant was not enforceable since, as required by its terms,

34 See U.S. Supreme Court Advisory Committee Rules for Civil Procedure: Proceedings 903 (Nov. 17, 1935) (unpublished archive) (on file with Manuscripts and Archives, Yale University Library, in Charles Edward Clark Papers, Box 94, Folder 4) (At the November 17, 1935, meeting of the Advisory Committee, Clark observed, "I think the Equity rule itself is greatly desirable to avoid ... because I am afraid that the Equity rule is clearly restrictive.").

35 See id. at 872 (Commenting on the optimal text of a provision governing class actions, Warren Olney, an attorney and one of the members of the Advisory Committee on the Federal Rules of Civil Procedure, observed, "We ought to leave that to the court, and leave it flexible, so that they can apply the reasons - apply a reasonable rule and apply it, perhaps, progressive rules as time goes on in connection with it.").

36 Zechariah Chafee, JR., Some Problems of EQuity $249-57$ (1950) (detailing the judicial struggle to interpret and apply Rule 23 ).

371966 Amendments, supra note 33, at 98-99; see also Benjamin Kaplan, Continuing Work of the Civil Committee: 1966 Amendments of the Federal Rules of Civil Procedure (I), 81 HARV. L. REV. 356, 375-85 (1967).

38311 U.S. 32 (1940).

39 Id. at $37-38$. 
ninety-five percent of the landowners had not endorsed it. ${ }^{40}$ The suit was filed in an Illinois state court. ${ }^{41}$ The plaintiffs argued that the question of enforceability had been resolved affirmatively in a prior representative suit to which the defendants, as members of the representative class, were bound. ${ }^{42}$ The Illinois Supreme Court agreed with the plaintiffs and enforced the covenant. ${ }^{43}$

On appeal, the U.S. Supreme Court overturned that decision. ${ }^{44}$ The Hansberry Court described representative suits as constituting a wellrecognized exception to the general principle that only parties to an action are bound by the court's judgment. ${ }^{45}$ However, that exception must satisfy due process. Thus, the procedure adopted in a representative action must "fairly insure[] the protection of the interests" of the absent class members. ${ }^{46}$ In the Court's words, "It is familiar doctrine of the federal courts that members of a class not present as parties to the litigation may be bound by the judgment where they are in fact adequately represented by parties who are present." The Court found that adequate representation was wanting in Hansberry because the plaintiffs in the initial action, who were seeking to enforce the covenant, did not have a shared interest with those property owners who opposed enforcement. ${ }^{48}$ In other words, adequacy of representation requires at a minimum a common interest with a shared goal. While due process would be satisfied when such is the case,

[i]t is quite another to hold that all those who are free alternatively either to assert rights or to challenge them are of a single class, so that any group merely because it is of the class so constituted, may be deemed adequately to represent any others of the class in litigating their interests in either alternative. Such a selection of representatives for purposes of litigation, whose substantial interests are not necessarily or even probably the same as those whom they are deemed to represent, does not afford that protection to absent parties which due process requires. ${ }^{49}$

40 Id.

41 Lee v. Hansberry, 24 N.E.2d 37, 38 (Ill. 1939).

42 Id.

43 Id. at 39-40.

44 Hansberry, 311 U.S. at 46.

45 Id. at 41.

46 Id. at 42.

47 Id. at $42-43$.

48 Id. at 44 (holding that the "procedure and the course of litigation sustained here by the plea of res judicata do not satisfy" the requirement of adequate representation).

49 Id. at 45. 
We might say that the demands of justice supersede the goal of efficiency when the purported representatives of the class do not share a common interest and goal with the class. We should also note that the Hansberry Court was not imposing a stringent dogma of due process that insisted on individual autonomy or any other principle other than the need for adequate representation.

\section{The Current Rule-1966 and Beyond}

The 1966 amendments to Rule 23 weren't truly amendments. They were dramatic revisions of the Rule that produced a wholesale replacement of the original rule and ushered in a new era of class actions. The amendments created a new framework that took class actions beyond the narrow confines of the original rule. Their ostensible goal was to make class actions more readily available when other joinder devices proved inadequate to the mission of a "just, speedy, and inexpensive determination of every action and proceeding." 50

As is well known, Rule 23(a) established the prerequisites to certify a class (numerosity, commonality, typicality, and adequacy), while Rule 23(b) described the types of representative actions that could qualify as a class action. ${ }^{51}$ Subsections (c) through (e) offered guidance as to the procedures to be followed in class action litigation. ${ }^{52}$

Rule 23 has been amended several times since 1966, most recently in $2017 .{ }^{53}$ However, the basic structure of the 1966 amendments remains at the core of the Rule, and subsections (a) and (b) still operate as the gateways to certification.

\section{Rule 23(a)}

The 1966 Advisory Committee's discussion of Rule 23(a) is spare; it essentially reiterates what is provided by the new text and notes that satisfaction of these prerequisites is necessary, but not sufficient, to justify class certification. ${ }^{54}$ To our thinking, though, subsection (a) deserved a more thoughtful elaboration. The Committee's discussion leaves one with the impression that the Rule imposes a mechanical checklist and, as we will see, that is precisely how the Supreme Court

\footnotetext{
50 FED. R. CIV. P. 1.

51 FED. R. CIV. P. 23.

$52 \mathrm{Id}$.

53 See 1966 Amendments, supra note 33, at 103.

54 Id. at 100.
} 
approaches subsection (a). But, in fact, subsection (a) embodies a profound principle of due process, specifically, the principle articulated by the Court in Hansberry. There, the Court saw representative suits as a pragmatic alternative to the usual rules of joinder that allowed a court to "proceed to a [binding] decree in suits where the number of those interested in the subject of the litigation is so great that their joinder as parties in conformity to the usual rules of procedure is impracticable." $" 55$ The availability of that pragmatic alternative was, however, qualified by the requirement of adequate representation. ${ }^{56}$

If we read Rule 23(a) through the lens of Hansberry, we see not a four-part checklist - each part carrying the weight of its own doctrinal standards - but rather the embodiment of the principles of due process. The coupling of numerosity with impracticability descends directly from the Hansberry decision. Pragmatic numerosity justifies a deviation from the usual rules of joinder and promotes the due process principles of fairness and efficiency by providing a method through which to adjudicate claims that would otherwise lie fallow. Similarly, Rule 23(a)'s requirements of commonality, typicality, and adequacy are directly drawn from the Hansberry Court's insistence, as a matter of due process, that the class representative share a common interest with the class members. ${ }^{57}$

What we have, therefore, is not a four-part test but a series of factors that inform the preliminary due process evaluation for class certification. In essence, those factors assist us in answering two straightforward questions. First, given the size of the potential class and taking account of other relevant practical considerations (e.g., geographic dispersion, cost effectiveness, lack of realistic alternatives), is a class action an appropriate alternative to the usual rules of joinder? Second, do the class members and their named representative share a common interest that will ensure the adequacy of representation? In short, Rule 23(a) invites an application of Hansberry and its vision of the due process of law.

\section{Rule 23(b)}

Having satisfied subsection (a), a party seeking class certification must show that the proposed class fits into one or more of the three

55 Hansberry v. Lee, 311 U.S. 32, 41 (1940).

56 See id. at $42-43$. ("[M]embers of a class not present as parties to the litigation may be bound by the judgment where they are in fact adequately represented by parties who are present....").

57 Id. at 42, 44-45. 
types described in subsection (b). ${ }^{58}$ Subsection (b)(1) operates as a class action version of Rule 19(a) and advances similar due process concerns by avoiding practical prejudice to an existing party or to a person who ought to be a party. As the Advisory Committee explained, subsection (b)(1)(A) is available when "[o]ne person may have rights against, or be under duties toward, numerous persons constituting a class, and be so positioned that conflicting or varying adjudications in lawsuits with individual members of the class might establish incompatible standards to govern his conduct." 59 And subsection (b)(1)(B) will apply to "situations where the judgment in a nouclass [sic] action by or against an individual member of the class, while not technically concluding the other members, might do so as a practical matter." 60 Thus, subsection (b)(1) comfortably advances the idea of due process by providing a joinder device through which justice can be reasonably, fairly, and efficiently pursued in the particular contexts covered by its two parts. To the extent due process is further implicated by a (b)(1) certification, it would be so on an as-applied basis.

Rule 23(b)(2) has a broader sweep. It applies when "the party opposing the class has acted or refused to act on grounds that apply generally to the class, so that final injunctive relief or corresponding declaratory relief is appropriate respecting the class as a whole." ${ }^{.61}$ In the Committee's words,

This subdivision is intended to reach situations where a party has taken action or refused to take action with respect to a class, and final relief of an injunctive nature or of a corresponding declaratory nature, settling the legality of the behavior with respect to the class as a

58 The current version of Rule 23(b)(1), subject only to stylistic alterations from the original text, provides:

A class action may be maintained if Rule 23(a) is satisfied and if:

(1) prosecuting separate actions by or against individual class members would create a risk of:

(A) inconsistent or varying adjudications with respect to individual class members that would establish incompatible standards of conduct for the party opposing the class; or

(B) adjudications with respect to individual class members that, as a practical matter, would be dispositive of the interests of the other members not parties to the individual adjudications or would substantially impair or impede their ability to protect their interests ....

FED. R. CIV. P. 23(b)(1).

591966 Amendments, supra note 33, at 100.

$60 \mathrm{Id}$. at $100-01$.

61 FED. R. CIV. P. 23(b)(2) (noting that the current version contains only stylistic alterations from the original text). 
whole, is appropriate. Declaratory relief "corresponds" to injunctive relief when as a practical matter it affords injunctive relief or serves as a basis for later injunctive relief. The subdivision does not extend to cases in which the appropriate final relief relates exclusively or predominantly to money damages. ${ }^{62}$

Thus, (b)(2) is about injunctive relief, but quite clearly the Committee anticipated that money damages would not be foreclosed in a (b)(2) action so long as damages weren't the exclusive or predominant remedy. In any event, the Committee cites civil rights actions as a paradigmatic example of a (b)(2) case. ${ }^{63}$ It is not clear, however, why civil rights actions, such as school desegregation cases, couldn't be easily and obviously certified under subsections (b)(1)(A) or (B). For example, a school district faced with multiple desegregation suits could find itself subject to incompatible orders, thereby satisfying (b)(1)(A). And the unnamed members of a potential class of parents or students could certainly suffer the type of practical prejudice (b)(1)(B) is designed to avoid. Little effort should be required to establish that civil rights class actions, such as school desegregation cases or prison condition cases, promote the idea of due process by providing a fair and efficient method through which to vindicate the rule of law (and particularly constitutional law). The Committee, however, elides this topic. Why (b)(2) was necessary to that mission is unclear.

The Advisory Committee offers a second type of action falling within the contours of (b)(2):

an action looking to specific or declaratory relief ... brought by a numerous class of purchasers, say retailers of a given description, against a seller alleged to have undertaken to sell to that class at prices higher than those set for other purchasers, say retailers of another description, when the applicable law forbids such a pricing differential. ${ }^{64}$

Interestingly, the Committee does not mention consumer litigation, and focuses instead on ordinary business disputes. This type of action would not fall naturally into either of the (b)(1) categories. It also involves some form of monetary relief. ${ }^{65}$ The potential due process concerns arising in this second type are of a different order than those pertaining to civil rights actions. Unlike civil rights cases, where the ultimate relief sought is collective and an end in itself, the ultimate

\footnotetext{
621966 Amendments, supra note 33, at 102.

63 See Wal-Mart Stores, Inc. v. Dukes, 564 U.S. 338, 361 (2011) (endorsing this view).

641966 Amendments, supra note 33, at 102.

65 The third type of (b)(2) suit cited by the Committee - class action challenging an unlawful tie-in-would also seem to fit neatly within the contours of (b)(1)(A). Id.
} 
relief in this second type is neither collective nor an end in itself. The end is some form of compensation or restitution to each member of the class. Surely some consideration of the due process ramifications for this distinct type of (b)(2) class was warranted. The Committee's deficiency here seems particularly unfortunate in light of the welldocumented lawyer-driven abuse that such consumer class actions have generated. ${ }^{66}$ Additionally, given subsection (b)(3) and its safeguards, why the Committee saw (b)(2) as the proper vehicle for this second type of action, as opposed to (b)(3), remains unclear.

Subsection (b)(3) ${ }^{67}$ applies where "class-action treatment is not as clearly called for," ${ }^{\prime 68}$ essentially taking us into the realm of individualized monetary damages. The text of the rule, then and now, reflects substantial due process concerns by imposing a heightened efficiency requirement (predominance and superiority) and by requiring, via subsection (c)(2), detailed notice to the class members, a right to be excluded, and an alternative right to participate through counsel. ${ }^{69}$ The due process legacy of each of these requirements is palpable, though the Committee has little to say on this topic.

66 See Linda S. Mullenix, Ending Class Actions as We Know Them: Rethinking the American Class Action, 64 EMORY L.J. 399, 434-35 (2014).

67 The current version of Rule 23(b)(3), subject only to stylistic alterations from the original text, provides:

A class action may be maintained if Rule 23(a) is satisfied and if . . . the court finds that the questions of law or fact common to class members predominate over any questions affecting only individual members, and that a class action is superior to other available methods for fairly and efficiently adjudicating the controversy. The matters pertinent to these findings include: (A) the class members' interests in individually controlling the prosecution or defense of separate actions; (B) the extent and nature of any litigation concerning the controversy already begun by or against class members; (C) the desirability or undesirability of concentrating the litigation of the claims in the particular forum; and (D) the likely difficulties in managing a class action.

FED. R. CIV. P. 23(b)(3).

681966 Amendments, supra note 33, at 102.

69 The original Rule (c)(2) provided that in (b)(3) actions "the court shall direct to the class members the best notice practicable under the circumstances" 1966 Amendments, supra note 33, at 97-98. The notice was required to inform the class member of the right to be excluded from the class, of the fact that the member will be bound by the judgment in the absence of such a request, and if no such request is made, of the right of the member to appear in the action through counsel. Id. at 98. In this way, subsection (c)(2) directly embraced the class member's due process rights to pursue his or her own claim independently and, alternatively, to appear through counsel in an action in which his or her rights would be at stake. The current versions of subsection (c)(2)(B) provide an even more thorough list of this due-process-premised notice requirement. FED. R. CIV. P. 23(c)(2)(B). 
In fact, the Advisory Committee's commentary to subsection (b)(3) is cryptic and noncommittal. ${ }^{70}$ We can't resist quoting the Committee's discussion of predominance in full:

The court is required to find, as a condition of holding that a class action may be maintained under this subdivision, that the questions common to the class predominate over the questions affecting individual members. It is only where this predominance exists that economies can be achieved by means of the class-action device. In this view, a fraud perpetrated on numerous persons by the use of similar misrepresentations may be an appealing situation for a class action, and it may remain so despite the need, if liability is found, for separate determination of the damages suffered by individuals within the class. On the other hand, although having some common core, a fraud case may be unsuited for treatment as a class action if there was material variation in the representations made or in the kinds or degrees of reliance by the persons to whom they were addressed. A "mass accident" resulting in injuries to numerous persons is ordinarily not appropriate for a class action because of the likelihood that significant questions, not only of damages but of liability and defenses to liability, would be present, affecting the individuals in different ways. In these circumstances an action conducted nominally as a class action would degenerate in practice into multiple lawsuits separately tried. Private damage claims by numerous individuals arising out of concerted antitrust violations may or may not involve predominating common questions. ${ }^{71}$

Beyond the first two sentences, which make perfect sense, it's hard to know what to make of the Committee's guidance. It goes something like this: predominance might be satisfied here, but maybe not, and it typically won't be satisfied there, but who knows, and it might or might not be satisfied in this other context, which is only marginally distinguishable from the first two. In the Committee's defense, the discussion of superiority is lucid and especially so in light of the non-

70 The current version of Rule 23(b)(3), subject only to stylistic alterations from the original text, provides:

A class action may be maintained if Rule 23(a) is satisfied and if . . the court finds that the questions of law or fact common to class members predominate over any questions affecting only individual members, and that a class action is superior to other available methods for fairly and efficiently adjudicating the controversy. The matters pertinent to these findings include: (A) the class members' interests in individually controlling the prosecution or defense of separate actions; (B) the extent and nature of any litigation concerning the controversy already begun by or against class members; (C) the desirability or undesirability of concentrating the litigation of the claims in the particular forum; and (D) the likely difficulties in managing a class action.

FED. R. CIV. P. 23(b)(3).

711966 Amendments, supra note 33, at 103 (citation omitted). 
exhaustive factors listed in subdivisions (b)(3)(A)-(D). ${ }^{72}$ No wonder courts have struggled with the elusive concept of predominance. ${ }^{73}$ The Committee's inexplicable and negative reference to mass torts is also quite unfortunate and seems to short-circuit the possibility that class actions could prove a useful device in that context.

We're still struggling with the tension between the Committee's descriptions of (b)(2) and (b)(3). As to (b)(2), according to the Committee, a class can seek monetary damages so long as those damages aren't the exclusive or predominant remedy. Presumably, the questions pertaining to the injunctive or declaratory relief must predominate over the damages claims. But under (b)(3), the common questions must also predominate over any individualized claims for monetary relief. Sounds remarkably similar. It could be that (b)(2) would only be appropriate for what we now identify as incidental damages and that (b)(3) would potentially be available for individualized damages (i.e., when the individual questions pertaining to those damages do not predominate).

Various other provisions of the original rule attended to the due process principles of fairness and efficiency, including subsection (d)'s outline of the various orders a court might enter during the pendency of the class action. ${ }^{74}$ Similarly, subsection (e) addressed itself, albeit cryptically, to the due process concerns arising in the context of class action settlements. Thus, "[a] class action shall not be dismissed or compromised without the approval of the court, and notice of the proposed dismissal or compromise shall be given to all members of the class in such manner as the court directs." 75

Rule 23(d) remains largely as originally conceived, but the newly adopted version of Rule 23(e) adds significant detail to the duties of the court and to the rights of class members (and potential class members) in the context of the settlement, voluntary dismissal or compromise of a certified class action, or of an action proposed to be certified for purposes of settlement. ${ }^{76}$ In other words, the new Rule 23(e) is anything but cryptic. The express aim of providing this detailed and

\footnotetext{
72 Id. at $97,103-04$.

73 Well these are the same folks who brought us the textual somersaults of Rule 19.

741966 Amendments, supra note 33, at 97 (original text), 106 ("Subdivision (d) is concerned with the fair and efficient conduct of the action and lists some types of orders which may be appropriate."). The current version of Rule 23(d) largely replicates the original rule. FED. R. CIV. P. 23(d)(1), (2).

751966 Amendments, supra note 33, at 105.

76 FED. R. CIV. P. 23(e)(1)-(5).
} 
rigorous approach to class-related settlements was to secure the due process rights of class members. ${ }^{77}$ As the 2017 Advisory Committee phrased it, "The central concern in reviewing a proposed class-action settlement is that it be fair, reasonable, and adequate." 78

More generally, from the text of Rule 23 and the commentary provided by the 1966 Advisory Committee (including Professor Kaplan's additional post-Committee commentary), it's not clear that the Committee had a completely coherent plan. ${ }^{79}$ The Committee saw the shortcomings of the original class action rule and definitely envisioned a more expansive role for the new rule. But how this new rule would, or should, work in practice seems not to have been fully understood, except in certain contexts where it did nothing more than replicate accepted practices. In terms of due process, the Committee did lock in some individual autonomy guarantees (e.g., opt out in (b)(3) actions) but didn't fully examine the due process possibilities that might be advanced by a more robust application of subsections (b)(2) and (b)(3). Due process should also take into account what we might call the rights of group autonomy. Like the original Advisory Committee, the 1966 Committee seemed to be looking backward at what worked and not forward toward the possibilities of collective action in a rapidly evolving litigation world. Of course, (b)(3) was correctly seen as inventive. But it was also shackled at birth by what appears to have been a lack of confidence in its possibilities and an overweening desire to adhere to the individual autonomy model of due process.

The current Rule 23 contains a number of other provisions designed to advance the idea of due process. For example, subsection (g) offers detailed guidance as to the appointment and duties of class counsel, a concern that was once deemed inherent in the due process requirement of adequacy of representation under Rule 23(a)(4). ${ }^{80}$ Relatedly, subsection (h) provides guidance to the court as to the award of attorney's fees. ${ }^{81}$ In general, Rule 23(a)-(h) can be seen as a reflection of the principles of due process as they occur in modern class action litigation. Those provisions, therefore, should not be treated as standalone concepts that invite an untethered form of doctrinal analysis.

77 ADVISORY COMMITTEE ON CIVIL RULES, 119-27 (April 2017), https://www.uscourts. gov/sites/default/files/2017-04-civil-agenda_book.pdf [https://perma.cc/9MA2-4AMZ].

78 Id. at 123 .

79 Kaplan, supra note 37, at 385-400.

80 FED. R. CIV. P. 23(g).

81 FED. R. CIV. P. 23(h). 
Rather, the idea of due process should form the foundation of any interpretation or application of Rule 23.

\section{The Rule in the Court's Jurisprudence}

Since the 1966 amendments, the Supreme Court has issued numerous decisions interpreting and applying Rule 23. Some of those decisions embraced the idea of due process while others did not. Reviewing a sampling of those decisions might help us identify the problems in the current jurisprudence of Rule 23 and formulate ideas for adjusting our approach to class actions, with the goal of making Rule 23 more truthful to the idea of due process.

\section{Amchem Products, Inc. v. Windsor}

At issue in Amchem Products, Inc. v. Windsor was the certifiability of a proposed settlement class purporting to resolve a broad spectrum of present and future asbestos-related claims. ${ }^{82}$ The settlement was intended to bind both symptomatic and asymptomatic persons who had been exposed to the defendants' products. The district court certified a settlement class, but the Third Circuit reversed. ${ }^{83}$ The defendants sought review in the Supreme Court.

The backstory of the settlement provides an important context to the Supreme Court's decision affirming the Third Circuit. ${ }^{84}$ Asbestosrelated litigation started as something of a trickle in the $1960 \mathrm{~s}$, but as the science and law became increasingly favorable to the plaintiffs, the trickle turned into to a river that overflowed its banks, eventually leading to litigation delays and stalemates, bankruptcies, and thousands of victims who were either under- or uncompensated. As to the numbers, "[f]rom 1980 through 1983, between 4,165 and 4,879 claims were filed every year. Between 1984 and 1987, filings more than quadrupled (to 21,056 per year). Thereafter, with the exception of 1989 , the yearly claims rate fluctuated between 22,752 and 29,883 through 1994." 85 This deluge of asbestos cases affected both state and federal courts.

After a series of aborted efforts to control the crisis, including urgent calls to Congress to intervene, the Judicial Panel on Multidistrict

\footnotetext{
$82 I d$.

83 Georgine v. Amchem Prods., Inc., 83 F.3d 610 (3d Cir. 1996).

84 For a fascinating and detailed account of the asbestos litigation crisis and the process through which the settlement was achieved, see Patrick M. Hanlon, An Experiment in Law Reform: Amchem Products v. Windsor, 46 U. MICH. J.L. REFORM 1279 (2013).

$85 \mathrm{Id}$. at 1286 (emphasis added).
} 
Litigation attempted to address the federal side of the crisis by consolidating all pending federal asbestos cases before a single judge in the United States District Court for the Eastern District of Pennsylvania. ${ }^{86}$ After lengthy and complicated negotiations, the parties eventually arrived at a settlement and sought to certify a settlement class. ${ }^{87}$ The proposed class included the following individuals:

(a) All persons (or their legal representatives) who have been exposed in the United States or its territories (or while working aboard U.S. military, merchant or passenger ships), either occupationally or through occupational exposure of a spouse or household member, to asbestos or to asbestos-containing products for which one or more of the defendants may bear legal liability and who, as of January 15, 1993, reside in the United States or its territories, and who have not, as of January 15, 1993, filed a lawsuit for asbestos-related personal injury or damage, or death in any state or federal court against the defendant(s) (or against entities for whose actions or omissions the defendant(s) bear legal liability).

(b) All spouses, parents, children, and other relatives (or their legal representatives) of the class members described in paragraph 1 above who have not, as of January 15, 1993, filed a lawsuit for the asbestosrelated personal injury, or damage, or death of a class member described in paragraph 1 above in any state or federal court against the defendant(s) (or against entities for whose actions or omissions the defendant(s) bear legal liability). ${ }^{88}$

As so defined, the class potentially included "hundreds of thousands, perhaps millions, of individuals." 89

The accompanying settlement was comprehensive, detailed, and purported to bind all persons who had been exposed to asbestos manufactured by the defendant companies, regardless of whether those persons were currently symptomatic of an asbestos-related disease. Described generally, the settlement created an administrative system through which persons suffering from one or more of four specified asbestos-related afflictions could receive compensation within a preset range specified for the particular disease or diseases at issue. As to asymptomatic exposure-only claimants, the settlement provided potential relief but no inflation adjustment or any accommodation for scientific developments that might indicate as yet unforeseen

86 Id. at 1298; Windsor, 521 U.S. at 599.

87 Windsor, 521 U.S. at 599-602.

88 Georgine v. Amchem Prods., Inc., 878 F. Supp. 716, 721 (E.D. Pa. 1994), rev'd, 83 F.3d 610 (3d Cir. 1996).

89 Windsor, 521 U.S. at 597. 
consequences of exposure to asbestos. ${ }^{90}$ The Court's description of the settlement is both acontextual and stated at a very general level. One must look to Justice Breyer's concurring and dissenting opinion for a more precise understanding of the complexities of the agreement and the various trade-offs that made the settlement possible: ${ }^{91}$

[C]ertain details of the settlement that are not discussed in the majority opinion suggest that the settlement may be of greater benefit to future plaintiffs than the majority suggests. The District Court concluded that future plaintiffs receive a "significant value" from the settlement due to a variety of its items that benefit future plaintiffs, such as: (1) tolling the statute of limitations so that class members "will no longer be forced to file premature lawsuits or risk their claims being time-barred"; (2) waiver of defenses to liability; (3) payment of claims, if and when members become sick, pursuant to the settlement's compensation standards, which avoids "the uncertainties, long delays and high transaction costs [including attorney's fees] of the tort system"; (4) "some assurance that there will be funds available if and when they get sick," based on the finding that each defendant "has shown an ability to fund the payment of all qualifying claims" under the settlement; and (5) the right to additional compensation if cancer develops (many settlements for plaintiffs with noncancerous conditions bar such additional claims). For these reasons, and others, the District Court found that the distinction between present and future plaintiffs was "illusory." 92

Part III of the Court's opinion provides a prosaic description of Rule 23, essentially tracking the 1966 Advisory Committee's Notes. ${ }^{93}$ Here the Court embraces much of the Advisory Committee's timidity with respect to subsection (b)(3) and seems to relegate (b)(3) actions to lowstakes cases in which individual class members do not have economically litigable claims. At the very least, in the Court's view, the higher the stakes, the more likely it is that common questions will not predominate and that individual actions will remain superior to class actions. Thus, "[w]hile the text of Rule 23(b)(3) does not exclude from certification cases in which individual damages run high, the Advisory Committee had dominantly in mind vindication of 'the rights of groups of people who individually would be without effective strength to bring their opponents into court at all."'94 This approach, whether it is definitive or merely presumptive, invites a mechanical and

\footnotetext{
$90 \mathrm{Id}$. at $602-05$.

91 Id. at 638-39 (Breyer, J., concurring and dissenting).

$92 \mathrm{Id}$. at 638 (citations omitted).

93 See id. at 613-19.

94 Id. at 617 (quoting Benjamin Kaplan, A Prefatory Note, 10 B.C. IND. \& COM. L. REV. 497, 497 (1969)).
} 
rigid reading of predominance, treating (b)(3) as nothing more than an efficiency tool for low-stake cases.

The Court opens the application portion of its opinion - part IV - by ruling that while a settlement agreement cannot displace the classqualifying criteria of subsections (a) and (b), the terms of a settlement should inform the application of those subsections. ${ }^{95}$ In short, the fairness of the settlement cannot itself justify certification, though the substance of the settlement is relevant in determining whether the classqualifying criteria have been established. ${ }^{96}$ The Court was unanimous on this point. But the majority's application of the principle seems lackadaisical at best.

As to predominance, the Court instructs the reader that the question is whether the class is "sufficiently cohesive." $" 97$ However, the Court only explained that term's meaning as another way of saying that the common questions should predominate. ${ }^{98}$ More to the point, the Court does not examine the terms of the settlement - as the court said it should - to inform the predominance inquiry. Nor does the Court examine efficiencies that might be advanced by settling a wide range of claims - as the court said it should - many of which would have transaction costs beyond their value. Instead, the Court simply and cryptically says that there are too many individual issues, and then notes that the court of appeals thought so as well. ${ }^{99}$ In the end, the class is just too "sprawling." 100

But the question the Court should have asked, by its own reckoning, was whether the settlement adequately navigated the individual issues in a manner that showed that the critical question - the health consequences of asbestos exposure - retained its predominance, both as a pre- and postsettlement matter. By way of contrast, Justice Breyer, concurring and dissenting, endorses and employs a pragmatic, detailed examination of the settlement and a more accurate assessment of predominance. His more detailed and realistic approach certainly gives

\footnotetext{
95 Id. at $619-22$.

$96 \mathrm{Id}$. at 621.

$97 \mathrm{Id}$. at 623 .

$98 \mathrm{Id}$.

99 Id. at 623-24.

$100 \mathrm{Id}$. at 624.
} 
one a very different sense of the case and of the utility and fairness of the proposed class-based settlement. ${ }^{101}$

The Court was troubled by the fact that the class, which included both symptomatic and asymptomatic members, reflected an inherent conflict of interest between those two groups, thus failing to satisfy the standards of Rule 23(a)(4). ${ }^{102}$ The evidence of this conflict was the claim by some objectors that the funds allocated in the settlement disadvantaged the asymptomatic exposure-only members of the class by, among other things, failing to include an adjustment for inflation.

101 Id. at 631-35. Justice Breyer's realistic assessment of the complexities facing the parties and district court also provided a much-needed context for any evaluation of the settlement agreement:

Delays, high costs, and a random pattern of noncompensation led the Judicial Conference Ad Hoc Committee on Asbestos Litigation to transfer all federal asbestos personal-injury cases to the Eastern District of Pennsylvania in an effort to bring about a fair and comprehensive settlement. It is worth considering a few of the Committee's comments. See Judicial Conference Report 2 ("“Decisions concerning thousands of deaths, millions of injuries, and billions of dollars are entangled in a litigation system whose strengths have increasingly been overshadowed by its weaknesses.' The ensuing five years have seen the picture worsen: increased filings, larger backlogs, higher costs, more bankruptcies and poorer prospects that judgments - if ever obtained — can be collected" (quoting Rand Corporation Institute for Civil Justice)); $i d$. at 13 ("The transaction costs associated with asbestos litigation are an unconscionable burden on the victims of asbestos disease." "[O]f each asbestos litigation dollar, 61 cents is consumed in transaction costs. ... Only 39 cents were paid to the asbestos victims" (citing Rand finding)); ("Delays also can increase transaction costs, especially the attorneys' fees paid by defendants at hourly rates. These costs reduce either the insurance fund or the company's assets, thereby reducing the funds available to pay pending and future claimants. By the end of the trial phase in [one case], at least seven defendants had declared bankruptcy (as a result of asbestos claims generally")).

Although the transfer of the federal asbestos cases did not produce a general settlement, it was intertwined with and led to a lengthy year-long negotiation between the cochairs of the Plaintiff's Multi-District Litigation Steering Committee (elected by the Plaintiff's Committee Members and approved by the District Court) and the 20 asbestos defendants who are before us here. These "protracted and vigorous" negotiations led to the present partial settlement, which will pay an estimated $\$ 1.3$ billion and compensate perhaps 100,000 class members in the first 10 years. "The negotiations included a substantial exchange of information" between class counsel and the 20 defendant companies, including "confidential data" showing the defendants' historical settlement averages, numbers of claims filed and settled, and insurance resources. "Virtually no provision" of the settlement "was not the subject of significant negotiation," and the settlement terms "changed substantially" during the negotiations. In the end, the negotiations produced a settlement that, the District Court determined based on its detailed review of the process, was "the result of arms-length adversarial negotiations by extraordinarily competent and experienced attorneys."

Id. at 632 .

102 Id. at $626-27$. 
This point certainly has the patina of credibility. But that credibility fades with the realization that some of the named plaintiffs were asymptomatic and presumably negotiated from that perspective and, more importantly, when one examines the settlement at a more detailed level and considers the various trade-offs made during the negotiations. Again, Justice Breyer's opinion provides a window into that possibility. ${ }^{103}$

From a due-process perspective, the Court's opinion falls woefully short. It is not clear that anyone's due process interests were furthered by this decision: not the plaintiffs' (both symptomatic and asymptomatic), not the defendants', not the community's, and not the judicial system's. Instead of treating Rule 23 as an opportunity to ameliorate a litigation (and human) crisis, the Court treated the rule as a barrier to that opportunity. An alternative approach would have been to ask whether, given the nature of the crisis and the precise contours of the negotiations and settlement, Rule 23 could be interpreted or applied in a manner that advanced the idea of due process: reasonableness, fairness, and efficiency. ${ }^{104}$ Ultimately, the Court's message to lower courts was don't be adventuresome, don't be too enthusiastic, and don't be a problem solver. ${ }^{105}$

\section{Ortiz v. Fibreboard Corp.}

Fibreboard Corporation was a timber company manufacturing a variety of products containing asbestos, mainly for high-temperature industrial applications. ${ }^{106}$ In the flood of asbestos litigation, Fibreboard was sued by an increasing number of personal injury plaintiffs. After litigating with its two potential insurers-Continental Casualty Company and Pacific Indemnity Company ${ }^{107}$ - a California state trial court in 1990 held the two insurers responsible for indemnification as to any claim by a claimant exposed to Fibreboard asbestos products and required the insurers to pay the full cost of defense for each claim

103 See id. at 638-39 (Breyer, J., concurring and dissenting); see supra text accompanying note 102 .

104 To be contrasted with the Court's nervous approach to Rule 23 is the bold and successful Dalkon Shield Claimants Trust, which had the benefit of not relying on Rule 23 but on the apparently more flexible bankruptcy law. See Georgene M. Vairo, Georgine, the Dalkon Shield Claimants Trust, and the Rhetoric of Mass Tort Claims Resolution, 31 LOY. L.A. L. REV. 79, 85 (1997).

105 Windsor, 521 U.S. at 628-29.

106 Ortiz v. Fibreboard Corp., 527 U.S. 815, 822 (1999).

107 Id. 
covered. ${ }^{108}$ While an appeal was pending, Fibreboard started approaching the plaintiffs who had filed claims against it and offered to settle such claims. ${ }^{109}$ Initially, the settlements provided a payment of forty percent of the plaintiffs' claims up front and the balance contingent upon a successful resolution of the insurance coverage dispute. ${ }^{110}$ However, with the increasing pace of the filings against it, Fibreboard began settling cases by assigning its rights against Continental, providing no initial payment, and offering a figure about twice the nominal amount of earlier settlements. ${ }^{111}$ Then the company decided to embark on global settlement negotiations with the remaining plaintiffs. ${ }^{112}$ Having lost at the trial court level on the coverage dispute, Continental joined the global settlement negotiations, but "conditioned its part in any settlement on a guarantee of "total peace." 113 Thus, the parties started talking about the feasibility of a mandatory class action that would bind all potential plaintiffs without giving them any choice to opt out. ${ }^{114}$ After several months, the parties finally agreed on a $\$ 1.535$ billion global settlement, with $\$ 1.525$ billion of this sum coming from Continental and Pacific and $\$ 10$ million to be paid by Fibreboard. ${ }^{115}$ The parties agreed to identify unsettled present claims against Fibreboard and set aside a then unspecified fund to resolve them. ${ }^{116}$ They also agreed that any excess left in that fund would be distributed to class claimants. ${ }^{117}$ At the insistence of plaintiffs' counsel, Fibreboard and its two insurers also entered into the "Trilateral Settlement Agreement," under which "[t]he two insurers agreed to provide Fibreboard with ... \$2 billion to defend against asbestos claimants and pay the winners" in case the global settlement agreement failed to win approval. ${ }^{118}$

On September 9, 1993, in an attempt to secure funds sufficient for compensation, a group of personal injury plaintiffs filed an action in the United States District Court for the Eastern District of Texas seeking certification for settlement of a mandatory class comprising

\footnotetext{
108 Id. at $822-23$.

$109 \mathrm{Id}$.

$110 \mathrm{Id}$. at 823.

$111 \mathrm{Id}$.

$112 \mathrm{Id}$.

113 Id. at 824.

$114 \mathrm{Id}$.

115 Id. at $824-25$.

$116 \mathrm{Id}$. at 825 .

117 Id.

$118 I d$.
} 
three groups: (1) "all persons with personal injury claims against Fibreboard for asbestos exposure who had not yet brought suit or settled their claims before" August 27, 1993; ${ }^{119}$ (2) those persons "who had dismissed such a claim but retained the right to bring a future action against Fibreboard; and [(3)] 'past, present, and future spouses, parents, children, and other relatives' of class members exposed to Fibreboard asbestos." 120 Thus, the class did not include claimants with actions still pending against Fibreboard "or claimants "who filed and, for cash payment or some other negotiated value, dismissed claims against Fibreboard, and whose only retained right [was] to sue Fibreboard upon development of an asbestos-related malignancy.",121

Continental and Pacific sought and obtained leave to intervene as defendants in the action. ${ }^{122}$ "The District Court provisionally granted class certification, enjoined commencement of further separate litigation against Fibreboard by class members, and appointed a guardian ad litem to review the fairness of the settlement to the class members." 123

Under the settlement agreement, in exchange for full releases from class members, Fibreboard, Continental, and Pacific would establish a trust to process and pay class members' asbestos personal injury and death claims. ${ }^{124}$ Claimants seeking compensation were required to try to settle with the trust. ${ }^{125}$ "If initial settlement attempts failed, claimants would have to proceed to mediation, arbitration, and a mandatory settlement conference." 126 Then, only after exhausting that process, defendants could sue the trust, subject to a limit of $\$ 500,000$ per claim, "with punitive damages and prejudgment interest barred."127 The "claims resolved without litigation would be discharged over three years, while judgments would be paid out over a 5-to-10-year period." 128 The "[a]greement also contained spendthrift provisions to

119 The insurance companies' appeal of the consolidated coverage case had been set to be heard on August 27, 1993; see id. at 824 .

120 Id. at $825-26$.

121 Id. at $826-27$.

122 Id. at 827.

$123 \mathrm{Id}$.

$124 \mathrm{Id}$.

$125 I d$.

$126 I d$.

$127 \mathrm{Id}$.

$128 I d$. 
conserve the trust, and provided for paying more serious claims first in the event of a shortfall in any given year."129

The district court cited the risk that Fibreboard might lose or fare poorly on appeal of the insurance coverage case or "lose the assignment-settlement dispute, leaving it without funds to pay all claims." ${ }^{130}$ Consequently, after an eight-day fairness hearing, the court certified the class under Rule 23(b)(1)(B) "and approved the settlement as 'fair, adequate, and reasonable"' under Rule 23(e). ${ }^{131}$ The district court dismissed the objectors' argument that the absence of a limited fund precluded certification under Rule 23(b)(1)(B), finding that there was no such restriction under the Rule, and that, if there was one, the case would still qualify. ${ }^{132}$

The Fifth Circuit affirmed the district court's opinion upholding its limited funds theory on the consideration "that Fibreboard [was facing] enormous potential liabilities and defense costs that would likely equal or exceed the amount of damages paid out."133 Judge Smith dissented on the basis of what he perceived to be major due process flaws in the majority opinion. ${ }^{134}$

Soon after, the Supreme Court decided Amchem and vacated and remanded the Fifth Circuit's judgment for further consideration in light of that decision. ${ }^{135}$ On remand, in a brief per curiam opinion, the Fifth Circuit again affirmed, distinguishing Amchem on the grounds that Amchem was a Rule 23(b)(3) action, whereas Fibreboard was a Rule 23(b)(1)(B) action. ${ }^{136}$ Judge Smith again dissented, rejecting the majority's limited fund theory because the fund had been made limited by the settlement itself. ${ }^{137}$ The Supreme Court granted certiorari and reversed. $^{138}$

The opinion of the Court, authored by Justice Souter, opened with the very powerful consideration that, "[1]ike Amchem[,] . . this case is a class action prompted by the elephantine mass of asbestos cases, and our discussion in Amchem will suffice to show how this litigation defies

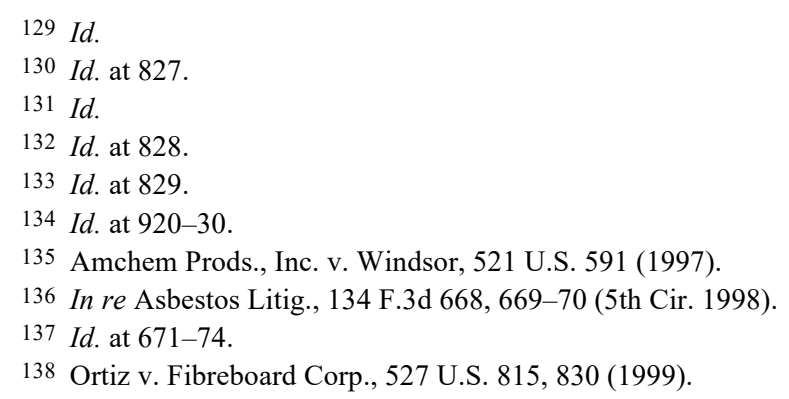


customary judicial administration and calls for national legislation."139 The Court noted that "[t]he Advisory Committee did not envision mandatory class actions in cases like this one, and both the Rules Enabling Act and the policy of avoiding serious constitutional issues counsel against leniency in recognizing mandatory limited fund actions in circumstances markedly different from the traditional paradigm." 140 But,

[a]ssuming, arguendo, that a mandatory, limited fund rationale could under some circumstances be applied to a settlement class of tort claimants, it would be essential that the fund be shown to be limited independently of the agreement of the parties to the action, and equally essential under Rules 23(a) and (b)(1)(B) that the class include all those with claims unsatisfied at the time of the settlement negotiations, with intraclass conflicts addressed by recognizing independently represented subclasses. ${ }^{141}$

Thus, the Court found the application of Rule 23(b)(1)(B) to be inappropriate in this case. ${ }^{142}$

As in Amchem, Justice Breyer dissented, starting from the same premise that had prompted the Court to reverse the Fifth Circuit, that is, the idea that the settlement before the Court was part of an "elephantine mass of asbestos cases," "43 which "defie[d] customary judicial administration." "144 But, according to Justice Breyer, the solution to this problem could not be found in "our 'deep-rooted historic tradition that everyone should have his own day in court.",145 And "[it was] the number of these cases, not their nature, that create[d] the special judicial problem," 146 so judges had to "search aggressively for ways, within the framework of existing law, to avoid delay and expense so great as to bring about a massive denial of justice." 147 Truthful to due process considerations, and with an analysis attentive to the reality of litigation and the plaintiffs' claims of rights, Justice Breyer emphasized that the district court's opinion was grounded in 446 factual findings, which had properly led the district court to conclude that the settlement was equitable, that the potential claimants

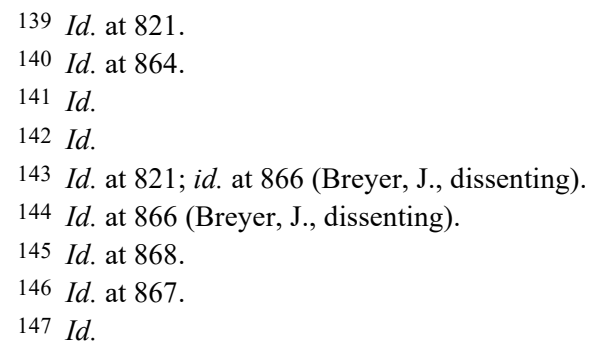


had been adequately "represented, and that the distinctions drawn among the different categories of claimants were reasonable." ${ }^{148}$ Those findings and conclusions, he noted, had also been affirmed by the Court of Appeals for the Fifth Circuit. ${ }^{149}$ In other words, the factual findings fully showed fairness and efficiency in the resolution of a problem of a certain magnitude and, in any event, the alternative to class action settlement was not going to be a fair opportunity for each plaintiff to litigate. ${ }^{150}$ It might have been no justice at all.

Justice Breyer believed this to be a limited fund case within Rule 23(b)(1)(B) because of the "significant 'risk' that the total assets available to satisfy the claims of the class members would fall well below the likely total value of those claims." ${ }^{151}$ As to the potential for unequal treatment among the claimants, the district court's seventy-six separate findings of fact pointing to an absence of such unequal treatment were enough for Justice Breyer to dispel such concern. ${ }^{152}$ Hence, certifying the settlement class would have provided justice consistent with due process. We might say that the majority opinion disserved the idea of due process, while Justice Breyer fully embraced and applied that idea.

\section{Wal-Mart Stores, Inc. v. Dukes}

The Court's opinion in Wal-Mart Stores, Inc. v. Dukes ${ }^{153}$ addressed two aspects of certification under Rule 23: the commonality component of subsection (a) and the availability of individualized damages under subsection (b)(2). ${ }^{154}$

As previously noted, Rule 23(a) deals with two interrelated concerns, namely, (1) whether it would make sense to proceed as a class action given the size of the class and the overall context of the litigation (numerosity), and if so, (2) whether the class members will be adequately represented by the named representatives (commonality, typicality, and adequacy). The first question played no role in the Court's discussion. Instead, the Court focused on a single component

\footnotetext{
148 Id. at 865 .

$149 \mathrm{Id}$.

$150 \mathrm{Id}$. at $867-68$.

151 Id. at 871.

152 Id. at 878.

153564 U.S. 338 (2011).

154 Id. at 342.
} 
of the second question. In the Court's words, "[T]he crux of this case is commonality." 155

The Court majority did recognize that commonality was part of an integrated inquiry into what we would call the Hansberry questionnamely, the question of whether the class members are (or were) adequately represented. In fact, the Wal-Mart Court's insistence on a litigation-driving common contention with a common answer flows directly from Hansberry. In Hansberry, the adequacy demanded by due process was to be found in a shared goal among the class members and their named representative with respect to a litigation-driving issue. ${ }^{156}$ The common, litigation-driving question in Wal-Mart was whether the defendant's corporate culture was the proximate cause of a practice or pattern of gender-based employment practices. ${ }^{157}$ The common answer or shared goal sought by the class and its representatives was an affirmative response to that question. ${ }^{158}$ To this point, the Wal-Mart Court's opinion accords with the due process character of class actions.

The opinion goes off the due-process rails, however, when it demands significant proof of the plaintiffs' Title VII theory as an aspect of commonality. ${ }^{159}$ The Court here imposes a doctrine of commonality that is untethered from the Hansberry question and the idea of due process. The majority, despite its protest to the contrary, transforms commonality into a freestanding, merit-based evaluation of the common question. One could argue that the majority was simply showing that there was no common question since each class member's claim would rise and fall on the discrete facts of her case. But that is not correct. The plaintiffs were challenging a perceived pattern or practice of discrimination emanating from a male-dominated corporate culture, and all members of the class certainly shared the goal of establishing that corporate-culture thesis, since doing so would create a rebuttable presumption of gender discrimination in their individual

155 Id. at 349.

156 See Hansberry v. Lee, 311 U.S. 32, 45 (1940).

157 Wal-Mart Stores, Inc., 564 U.S. at 355-58.

158 Id. at $350-52$.

159 Id. at 349 n.5 (quoting Gen. Tel. Co. of Sw. v. Falcon, 457 U.S. 147, 157-58 n.13 (1982)). The "significant proof" language was extracted from a footnote in the Falcon opinion. That footnote reads more like an aside than it does the creation of a certification standard of proof. In the body of the Falcon opinion, the Court focuses on the pleadings as the vehicle for measuring commonality. Falcon, 457 U.S. at 158 ("Respondent's complaint provided an insufficient basis for concluding that the adjudication of his claim of discrimination in promotion would require the decision of any common question concerning the failure of petitioner to hire more Mexican-Americans."). 
claims. In the end, the majority simply didn't believe (or refused to believe) that the plaintiffs' theory could be sustained on the evidence presented. This, however, has nothing to do with the Hansberry adequacy of representation principle requiring a common contention seeking a common answer. The majority's significant proof requirement elided the due process issue that Rule 23(a)(2)-(4) is designed to address, and simultaneously undermined the due process rights of the class by disposing of the merits of a significant aspect of their collective claims at the certification stage.

The second question presented to the Court was whether a class certified under Rule 23(b)(2) could include individualized claims for money damages. ${ }^{160}$ The Court unanimously responded that Rule 23(b)(2) may not be so used. ${ }^{161}$ The due process defense of this position would focus on the absence of notice and opt-out requirements in (b)(2) actions. And from a legislative intent perspective, the argument against allowing individualized damages in a (b)(2) class action was that the Advisory Committee wouldn't have wanted (b)(2) to be used as an end run around the more demanding requirements (b)(3) imposed. But it isn't clear that these arguments should have carried the day. As for the Advisory Committee's intent, it's far from certain what the Committee truly intended with respect to the relationship between (b)(2) and (b)(3). As noted previously, the Advisory Committee seemed to have thought that a (b)(2) action could include money damages so long as those damages weren't the exclusive or predominant remedy. ${ }^{162}$

Justice Scalia rejected this negative inference on the view that the Committee wouldn't have wanted (b)(2) to undermine the standards of (b)(3). ${ }^{163}$ But it is equally likely, and more consistent with the Committee's commentary, that the Committee was unsure of the scope of (b)(3) and might well have endorsed some overlap between the two subsections. As noted previously, there was clear overlap between (b)(1) and (b)(2).

In any event, from a due process perspective, it's true that the higher standards imposed on (b)(3) certifications are designed to ensure due process. But the scope of due process is not predetermined or rigid, as the Court so often reminds us. And there certainly could be some cases

160 Wal-Mart Stores, Inc., 564 U.S. at 367-68 (Ginsburg, J., concurring and dissenting).

161 Id. at 360-61.

$162 I d$. at 363.

163 Id. at 363-64. 
where the requirement of notice and the right to opt out might outweigh other due process concerns, including the community's rights and interests, transaction costs, and efficiency. Hence, a black-letter rule limiting the scope of (b)(2) class actions disserves due process by demanding a form of acontextual uniformity. A more sensible and dueprocess driven approach in Wal-Mart would have confined the ruling to address only whether (b)(2) certification was appropriate under the precise circumstances of that case.

\title{
7. Amgen Inc. v. Connecticut Retirement Plans and Trust Funds
}

At first blush, the Court's decision in Amgen Inc. v. Connecticut Retirement Plans and Trust Funds appears to flip Justice Scalia's merits-based approach to commonality on its head. ${ }^{164}$ There has been much rejoicing in the majority's observation:

\begin{abstract}
Although we have cautioned that a court's class-certification analysis must be "rigorous" and may "entail some overlap with the merits of the plaintiff"s underlying claim," Wal-Mart Stores, Inc. v. Dukes, 564 U.S. 338, 351 (2011) (internal quotation marks omitted), Rule 23 grants courts no license to engage in free-ranging merits inquiries at the certification stage. Merits questions may be considered to the extent - but only to the extent - that they are relevant to determining whether the Rule 23 prerequisites for class certification are satisfied. ${ }^{165}$
\end{abstract}

But the Court's application of the commonality principle was not quite as bold as the above quotation might lead one to believe. In fact, perhaps as a product of Supreme Court politics, ${ }^{166}$ the Amgen Court added yet another layer to the stand-alone doctrine of commonality, creating another microdoctrine over which litigants will find themselves splitting hairs.

The plaintiffs in Amgen filed a securities fraud complaint against Amgen, a biotechnology company. Their complaint alleged that Amgen's misrepresentations and omissions materially affected the company's stock price in violation of the Securities and Exchange Act of $1934 \S 10(\mathrm{~b})$ and Securities and Exchange Commission Rule 10b-5. The plaintiffs sought to certify a class of similarly situated investors who purchased Amgen stock during the relevant time frame. To prevail on their claim, the plaintiffs (and all members of the class) would have

164568 U.S. 455 (2013).

165 Id. at $465-66$.

166 Justice Ginsburg, the author of the majority opinion, needed Justice Alito's vote to secure a majority. 
to prove the materiality of the challenged misrepresentations and omissions. But the plaintiffs hoped to avoid proving individual reliance by resorting to the fraud on the market presumption.

The only issue before the Court was whether the plaintiffs had satisfied the predominance requirement of Rule 23(b)(3). Amgen argued that the plaintiffs were required to prove materiality at the certification stage yet failed to do so. The Court rejected that argument for two reasons. First, materiality was a common question since it could be "proved through evidence common to the class." 167 Second, and most importantly,

there [wa]s no risk whatever that a failure of proof on the common question of materiality w[ould] result in individual questions predominating. Because materiality is an essential element of a Rule 10b-5 claim ... Connecticut Retirement's failure to present sufficient evidence of materiality to defeat a summary-judgment motion or to prevail at trial would not cause individual reliance questions to overwhelm the questions common to the class. Instead, the failure of proof on the element of materiality would end the case for one and for all; no claim would remain in which individual reliance issues could potentially predominate. ${ }^{168}$

We would call this the death knell approach to predominance: if a failure to prove is the death knell of the individual claims, predominance is satisfied.

We have no quarrel with the death knell rule as a matter of sufficiency, except that Justice Ginsburg seems to be treating it as a matter of necessity. Suppose the common question had been fraud on the market. A failure to establish that presumption would not have been the death knell to individual claims, since each individual could attempt to prove actual reliance. Hence, either predominance could not be established given the absence of a death knell, or plaintiffs would be required to prove fraud on the market prior to certification. In this regard, consider Justice Ginsburg's response to the dissent:

A failure of proof on the common question of materiality ends the litigation and thus will never cause individual questions of reliance or anything else to overwhelm questions common to the class. Therefore, under the plain language of Rule 23(b)(3), plaintiffs are not required to prove materiality at the class-certification stage. In other words, they need not, at that threshold, prove that the predominating question will be answered in their favor. ${ }^{169}$

167 Id. at 467.

168 Id. at $467-68$.

169 Id. at 468 . 
By inference, the plaintiffs would have to prove their common contention at the outset if its failure would not operate as a death knell. If that is correct, it follows that a (b)(3) class certification in Wal-Mart would have failed the predominance test because failure of the corporate-culture thesis would not have been the death knell to a wide range of individual claims. Moreover, (at least according to the majority) the plaintiffs failed to prove their thesis prior to certification.

One would think that the better approach to failure of proof would be to decertify the class if the common questions no longer predominated. Rule 23(c)(1)(C) would seem ideally suited to that task. ${ }^{170}$ But it is not clear how this refinement of predominance will advance the principles of due process. Refinement seems much more likely to clutter certification with an unnecessary doctrinal complexity. We do agree that this form of failure-of-all-claims predominance is sufficient to justify certification, but it doesn't follow that it should be necessary.

\section{Jennings v. Rodriguez}

The precise issue presented in Jennings $v$. Rodriguez was whether aliens who have been detained pending immigration removal proceedings for longer than six months have a right to a bond hearing. ${ }^{171}$ Rodriguez, who was so detained, joined other similarly situated detainees and sought certification of a class to challenge the practice on constitutional and statutory grounds. ${ }^{172}$ The district court denied certification, but the Ninth Circuit reversed and remanded. ${ }^{173}$ On remand, the district court certified the following class (naming Rodriguez as the class representative):

[A]11 non-citizens within the Central District of California who: (1) are or were detained for longer than six months pursuant to one of the general immigration detention statutes pending completion of removal proceedings, including judicial review, (2) are not and have not been detained pursuant to a national security detention statute, and (3) have not been afforded a hearing to determine whether their detention is justified. ${ }^{174}$

\footnotetext{
170 FED. R. CIV. P. 23(c)(1)(C) ("An order that grants or denies class certification may be altered or amended before final judgment.").

171138 S. Ct. 830 (2018).

$172 \mathrm{Id}$. at 838.

$173 \mathrm{Id}$.

174 Id. at $838-39$.
} 
The district court also approved subclasses corresponding to each of the four statutes under which the class members were being detained8 U.S.C. $\S \S 1225$ (b) (inadmissible at arrival), 1226(a) (detained as inadmissible while in the United States), 1226(c) (legally in the United States but removable by virtue of having committed a specified crime), and 1231(a) (in process of removal, but not subject to a final removal order). ${ }^{175}$ On appeal, the Ninth Circuit affirmed the certification of the overall class and the first three of the four subclasses. ${ }^{176}$

On the merits, the district court upheld the claim and entered a permanent injunction against the government, which required a bond hearing for those detainees held over six months. ${ }^{177}$ The Ninth Circuit affirmed and, in doing so, applied the canon of constitutional avoidance and interpreted the relevant immigration statutes as providing the right to a bond hearing. The Supreme Court reversed, finding no such statutory right, ${ }^{178}$ and remanded to the Ninth Circuit for consideration of Rodriguez's constitutional claim. ${ }^{179}$ In remanding, the Court instructed the Ninth Circuit to reconsider the question of class certification. ${ }^{180}$ Specifically, the Court instructed the Ninth Circuit to

first decide whether it continues to have jurisdiction despite 8 U.S.C. $\S 1252(\mathrm{f})(1)$. Under that provision, "no court (other than the Supreme Court) shall have jurisdiction or authority to enjoin or restrain the operation of [\$§1221-1232] other than with respect to the application of such provisions to an individual alien against whom proceedings under such part have been initiated." Section 1252(f)(1) thus "prohibits federal courts from granting classwide injunctive relief against the operation of $\S \S 1221-123[2] . "$ The Court of Appeals held that this provision did not affect its jurisdiction over respondents' statutory claims because those claims did not "seek to enjoin the operation of the immigration detention statutes, but to enjoin conduct ... not authorized by the statutes." This reasoning does not seem to apply to an order granting relief on constitutional grounds, and therefore the Court of Appeals should consider on remand whether it may issue classwide injunctive relief based on respondents' constitutional claims. If not, and if the Court of Appeals concludes that it may issue only declaratory relief, then the Court of

\footnotetext{
175 Id. at 389.

176 Id.

$177 \mathrm{Id}$.

178 Id. at $842-48$.

$179 \mathrm{Id}$. at 851.

180 Id. The Court also instructed the Ninth Circuit to consider whether 8 U.S.C. $\S$ 1252(f)(1) divested the Ninth Circuit of jurisdiction now that the statutory issue had been resolved against the plaintiff.
} 
Appeals should decide whether that remedy can sustain the class on its own.

The Court of Appeals should also consider whether a Rule 23(b)(2) class action continues to be the appropriate vehicle for respondents' claims in light of Wal-Mart Stores, Inc. v. Dukes, 564 U.S. 338 (2011). We held in Dukes that "Rule 23(b)(2) applies only when a single injunction or declaratory judgment would provide relief to each member of the class." That holding may be relevant on remand because the Court of Appeals has already acknowledged that some members of the certified class may not be entitled to bond hearings as a constitutional matter. Assuming that is correct, then it may no longer be true that the complained-of " "conduct is such that it can be enjoined or declared unlawful only as to all of the class members or as to none of them."'

Similarly, the Court of Appeals should also consider on remand whether a Rule 23(b)(2) class action litigated on common facts is an appropriate way to resolve respondents' Due Process Clause claims. "[D]ue process is flexible," we have stressed repeatedly, and it "calls for such procedural protections as the particular situation demands." 181

The Court's first instruction raises questions pertaining to the jurisdictional scope of 8 U.S.C. $\S 1252(f)(1),{ }^{182}$ which places limits on the availability of injunctive relief in certain specific removal proceedings. While the Court observed that $(\mathrm{f})(1)$ "prohibits federal courts from granting classwide injunctive relief against the operation of" those removal proceedings, ${ }^{183}$ the text of (f)(1) doesn't literally say that, and the Court has never so held. The plaintiffs, in their supplemental brief to the Ninth Circuit, focused on the text of (f)(1), which, after seeming to prohibit all injunctive relief by courts other than the U.S. Supreme Court, creates an exception where an injunction is sought by an "individual alien against whom proceedings under such

181 Id. at $851-52$ (citation omitted). The Ninth Circuit directed the parties to file supplemental briefs on the above question as well as on the underlying constitutional issue. Rodriguez v. Jennings, 887 F.3d 954 (9th Cir. 2018).

182 The text of 8 U.S.C. $\S 1252(\mathrm{f})(1)$ provides:

Regardless of the nature of the action or claim or of the identity of the party or parties bringing the action, no court (other than the Supreme Court) shall have jurisdiction or authority to enjoin or restrain the operation of the provisions of part IV of this subchapter, as amended by the Illegal Immigration Reform and Immigrant Responsibility Act of 1996, other than with respect to the application of such provisions to an individual alien against whom proceedings under such part have been initiated.

183 See Jennings, 138 S. Ct. at 851 (quoting Reno v. American-Arab Anti-Discrimination Comm., 525 U.S. 471, 481 (1999)). 
part have been initiated."184 From this, the plaintiffs argued that classwide injunctive relief is available when removal proceedings have been initiated against all named plaintiffs and class members, which was the case with respect to the Rodriguez class action. ${ }^{185}$ We could say that this is a classic due process efficiency and fairness interpretation of (f)(1). The government, however, disputed the plaintiff's interpretation, focusing on the general intent behind the adoption of that provision, which was to bar injunctive relief by lower federal courts in all cases except those involving an individual proceeding. ${ }^{186}$ This question has less to do with class actions than it has to do with the perceived scope of (f)(1). For present purposes, we will presume that the government will prevail on this issue.

With the above presumption in mind, the critical question as to the Court's remand instructions is whether a (b)(2) class can seek corresponding declaratory relief consistent with (f)(1)'s bar on classwide injunctive relief.

According to the 1966 Advisory Committee Notes, "Declaratory relief 'corresponds' to injunctive relief when as a practical matter it affords injunctive relief or serves as a basis for later injunctive relief." ${ }^{187}$ We are aware of no dispute over this definition. Consistent with this, the plaintiffs plausibly argued that classwide declaratory relief would correspond to injunctive relief since individual detainees could use a declaration establishing the unconstitutionality of prolonged detention without a bond hearing as the basis for an injunction preventing the government from denying a timely bond hearing on a case-by-case basis. ${ }^{188}$ Importantly, since (f)(1) permits injunctions sought by individuals against whom proceedings have been initiated, the availability of declaratory relief would appear to be wholly consistent with the statutory scheme as it would allow the individual, relying on the declaration, to seek an injunction ordering such a hearing. It would also conform with the norm of due process to the extent that it promotes efficiency and fairness by resolving the critical question in one formal proceeding. The government, however, did not address this question, relying instead on the law of the case

184 Petitioners-Appellees Supplemental Brief at 7-10, Rodriguez v. Robbins, 803 F.3d 502 (9th Cir. 2015) (No. 13-56706 \& 13-56755) [hereinafter PASB].

$185 \mathrm{Id}$.

186 Respondents-Appellants' Corrected Supplemental Brief at 12-15, Rodriguez v. Marin, 909 F.3d 252 (9th Cir. 2018) (No. 13-56706 \& 13-56755) [hereinafter RACS].

1871966 Amendments, supra note 33, at 102.

188 PASB, supra note 184, at 14-18. 
since the panel had previously held that the award of declaratory relief would be inconsistent with (f)(1). ${ }^{189}$

The second paragraph of the Court's instructions seemed to invite a broad inquiry into what we might call the unitary relief principle described in Wal-Mart v. Dukes. But read in its entirety, the paragraph is more precisely focused on the entry fiction - a legal fiction under which noncitizens seeking entry into the United States and detained within the United States are treated as remaining at the border and, therefore, beyond the protection of the Constitution. ${ }^{190}$ To mask this fiction as presenting a Rule 23(b)(2) issue speaks volumes about this Court. In any event, Justice Breyer's dissent forcefully and persuasively exposed the vulgarity of the fiction. ${ }^{191}$ In any event, this fiction would only apply to one of the three subclasses - the subclass designated under $\S 1225$ (b) (inadmissible on arrival). Even a court that wanted to entertain the fiction might find additional space for providing basic due process protections to those subject to the entry fiction.

189 RACS, supra note 186 , at 15 n.1.

190 Rodriguez v. Robbins, 804 F.3d 1060, 1082-83 (9th Cir. 2015) (describing the fiction and its consequences), rev'd, 138 S. Ct. 830 (2018).

191 In Justice Breyer's words:

It is clear that the Fifth Amendment's protections extend to "all persons within the territory of the United States." But the Government suggests that those protections do not apply to asylum seekers or other arriving aliens because the law treats arriving aliens as if they had never entered the United States; hence they are not held within its territory.

This last-mentioned statement is, of course, false. All of these noncitizens are held within the territory of the United States at an immigration detention facility. Those who enter at JFK airport are held in immigration detention facilities in, e.g., New York; those who arrive in El Paso are held in, e.g., Texas. At most one might say that they are "constructively" held outside the United States: the word "constructive" signaling that we indulge in a "legal fiction," shutting our eyes to the truth. But once we admit to uttering a legal fiction, we highlight, we do not answer, the relevant question: Why should we engage in this legal fiction here?

The legal answer to this question is clear. We cannot here engage in this legal fiction. No one can claim, nor since the time of slavery has anyone to my knowledge successfully claimed, that persons held within the United States are totally without constitutional protection. Whatever the fiction, would the Constitution leave the Government free to starve, beat, or lash those held within our boundaries? If not, then, whatever the fiction, how can the Constitution authorize the Government to imprison arbitrarily those who, whatever we might pretend, are in reality right here in the United States? The answer is that the Constitution does not authorize arbitrary detention. And the reason that is so is simple: Freedom from arbitrary detention is as ancient and important a right as any found within the Constitution's boundaries.

Jennings, 138 S. Ct. at 862-63 (Breyer, J., dissenting) (emphasis in original) (citation omitted). 
The final and crucial paragraph for our purposes instructs the Ninth Circuit to consider whether a class action unified by common facts provides an appropriate vehicle for the resolution of due process claims. The subtextual implication is that due process is inherently flexible and, therefore, not amenable to a singular, class-based resolution. This is nonsense and bespeaks a fundamental misunderstanding of due process.

It is true that due process is flexible. And it is equally true that fairness, reasonableness, and efficiency are dependent on the specific circumstances of the case and invite a balancing of interests. ${ }^{192}$ Notice satisfactory in one context might not be satisfactory in another. But it does not follow that due process is ad hoc or that it is sized to fit only one occasion. From a fairness perspective, due process presumes that similarly situated persons under similar circumstances should be subject to the same established standards. Reasonableness and efficiency suggest that the context should inform the contours of the applicable standard. Thus, the minimum contacts standard of personal jurisdiction is uniform across the spectrum in which it appliespurposeful contacts, relatedness, and reasonableness - but is also sufficiently flexible to adapt to a range of circumstances. ${ }^{193}$ Here, the Court seems completely unmoored from the constitutional principle when it suggests that flexible due process may not be the appropriate common question for class certification.

The correct question in Jennings is not whether due process claims can be resolved in a common-facts class action, but whether in this particular class action, with three specified subclasses, a court can fashion a due process standard that is sufficiently comprehensive to define the scope of the right for all class or subclass members. The due process standard should be sufficiently comprehensive to accommodate the common contention and to resolve the question as to whether the detainees are entitled to a bond hearing after six months in detention. Of course, it's worth noting that the right asserted is to receive a hearing, not to obtain immediate release. Hence, the right affords the government an opportunity to explain why any particular detainee should not be entitled to a bond.

The core principle of our rule-of-law system is due process. A civil rights class action pursuing due process represents the quintessence of

192 See Mathews v. Eldridge, 424 U.S. 319, 333 (1976).

193 See Allan Ides, Christopher N. May \& Simona Grossi, Civil Procedure: CASES AND PROBLEMS 115-243 (5th ed. 2016) (detailing the law of personal jurisdiction). 
that principle. The Jennings Court seemed to have lost sight of that simple fact.

\section{Nutraceutical Corp. v. Lambert}

At issue in Nutraceutical Corp. v. Lambert ${ }^{194}$ was whether Rule 23(f)'s fourteen-day limitation on filing a petition for permission to appeal is subject to equitable tolling. ${ }^{195}$ The Court unanimously held that Rule 23(f) was not subject to equitable tolling, relying largely on the text of the federal rules, both civil and appellate, and on analogous precedent.

The district court in Nutraceutical ordered decertification of a class. Ten days after entry of that order, the plaintiff informed the court that he planned to file a motion for reconsideration. The court gave him ten more days to file that motion and the plaintiff followed the court's instructions. Once the motion was filed, the court took it under advisement and entered an order denying that motion three months later. Within fourteen days of that order, the plaintiff filed a Rule 23(f) petition for permission to appeal. The court of appeals granted the petition, explaining that Rule 23(f)'s nonjurisdictional time frame was subject to equitable tolling under the circumstances presented. ${ }^{196}$

The Supreme Court agreed that Rule 23(f) was nonjurisdictional. ${ }^{197}$ And it agreed that had the plaintiff filed his motion for reconsideration within the fourteen-day time frame, the date on which that motion was denied would open a new fourteen-day window within which to file a petition for permission to appeal. ${ }^{198}$ The problem, according to the Court, was that although the plaintiff announced his intent to file a motion for reconsideration within fourteen days of the order decertifying the class, his motion was filed after the fourteen-day limitation to petition for permission to appeal had expired. ${ }^{199}$

In declining to permit equitable tolling, the Court began and ended with the text of the rules. The Court noted that "the governing rules speak directly to the issue of Rule 23(f)'s flexibility and make clear that its deadline is not subject to equitable tolling." "200 This was because the text of Rule 23(f) expressly imposed a fourteen-day time frame within

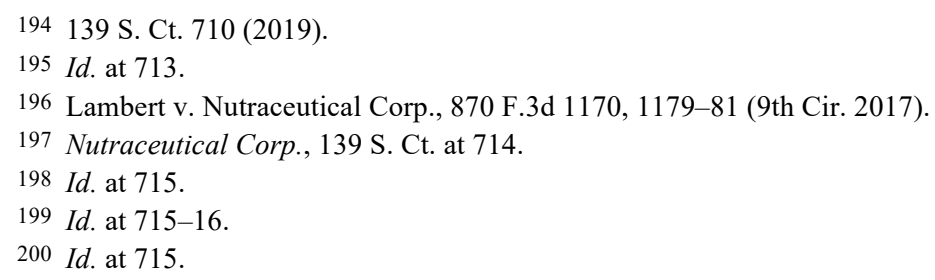


which to file the petition, and although appellate Rule 26(b) allowed various court-ordered extensions of time, it expressly prohibited any extension "to file ... a petition for permission to appeal.",201

As to the scope of Rule 26(b), the plaintiff argued that the text of the rule was more nuanced in that it distinguished between extending the time within which to file a petition (an ex ante request to extend) and excusing the failure to file within the specified time frame (an ex post request to excuse). In fact, the text of the rule expressly prohibits only the former - the ex ante request - and would, by inference, seem to permit the latter. ${ }^{202}$ The Court did not disagree with the plaintiff's reading of the text but concluded that any such reading was precluded by a 1960 decision construing the Federal Rules of Criminal Procedure. $^{203}$ The Court did not say that this prior decision was correctly decided. Rather, it simply said that the question had been decided in an analogous context, eliding any discussion of the merits of the plaintiff's contention or of the previous decision.

The Court also declined to decide two purely legal issues that the lower court did not address. The first issue was whether the timeliness of the plaintiff's motion to reconsider caused the petition filing time to run from the order denying that motion - as it would if he had filed the motion to reconsider within fourteen days of the initial order decertifying the class. The second issue was whether the district court's order denying the motion to reconsider was itself "an order granting or denying class-certification" within the meaning of Rule 23(f). ${ }^{204}$ Both were purely legal questions that could be answered without reference to any particular set of facts.

From a due process perspective, one might argue that the Court simply read the rules and applied them, thus adhering to the law and conforming its decision to the idea of due process. Of course, we praise a careful reading and enforcement of the rules' text. But a due process reading of the text should always begin with or be informed by the idea of due process - that is to say, justice that is reasonably, fairly, and efficiently pursued. That idea is embodied in Rule 1 and ought to permeate the interpretation of every rule. ${ }^{205}$ Moreover, the notion that

201 Id. (quoting FED. R. APP. P. 26(b)(1)).

202 Id. at 714.

203 Id. (citing United States v. Robinson, 361 U.S. 220 (1960)).

204 Id.

205 FED. R. CIV. P. 1 ("These rules govern the procedure in all civil actions and proceedings in the United States district courts, except as stated in Rule 81. They should be 
equitable principles ought not to be applied to the application of a federal rule is counterintuitive. The idea of equity is a product of due process, designed to provide justice where the law has failed to do so. The Court attended to none of this. It read the sanitized rule and purported to apply it, presumably on the umpire theory of judicial decision-making.

The plaintiff's effort to distinguish between extensions and excusals did evoke due process. It suggested a complementary reading of Rules 23(f) and 26(b), one that offered the type of due-process flexibility Rule 1 invites. The argument certainly merited something more than the Court's observation that the question had been decided adversely over fifty years ago in an analogous context. Because the text of the rule distinguishes between extensions and excusals, a consideration of the idea of due process might have helped the Court understand why the text does so.

The facts here strongly suggest that the fair, just, and most efficient resolution of this case would have been to allow the petition to be filed. But the Court said, in essence, that the road was previously paved otherwise, and it would not look beneath the surface.

Similarly, the Court's refusal to consider the plaintiff's other arguments - both of which raised pure questions of law and were inherently part of the case - also runs counter to the idea of due process. It is certainly not clear to us how the court of appeals is in any better position to decide these questions than was the Supreme Court. The principle that the lower courts should be the first to consider an issue is a salutary, general principle of judicial practice. But the Court only adheres to that principle unless it doesn't want to. It shouldn't have wanted to here.

The plaintiff's first alternative argument was that a timely motion to reconsider deflects the time frame for petitioning for permission to appeal to the date on which that motion is resolved. That argument is merely another way of applying the concept of equity to the interpretation of Rule 23(f). It's less ad hoc than a fairness-under-thecircumstances approach, but it rests on the same principles of justice and efficiency. Hence, the Court could have said one reason for denying equitable tolling was that equity was built in the rule whenever a plaintiff files a timely motion to reconsider a denial of class certification.

construed, administered, and employed by the court and the parties to secure the just, speedy, and inexpensive determination of every action and proceeding."). 
We would say that the decision in Nutraceutical disserves the idea of due process in at least three ways. First, it begins with the text and not with the idea of due process behind the text, treating the text as a stand-alone value. Second, it endorses an interpretation of the text that is largely compelled by reference to an analogous decision that was neither defended nor assessed in the Nutraceutical decision. Third, it fails to complete the task of interpretation, relying on a standard that is routinely ignored in the Court's common practices. Thus, while the Court's opinion has the patina of textual rationality, it fails to advance the mission of due process in an apparent effort to achieve unanimity and dispose of the case.

\section{China Agritech, Inc. v. Resh}

In American Pipe \& Construction Co. v. Utah, the Supreme Court held that the timely filing of a class action tolled the statute of limitations for all putative class members. ${ }^{206}$ It further held that members of a failed class action could intervene in that proceeding as individual plaintiffs after the denial of class certification. The Court clarified the American Pipe standard in Crown, Cork \& Seal Co. v. Parker ${ }^{207}$ where it held that such putative class members need not intervene in the pending suit to benefit from equitable tolling but could instead file independent actions asserting the same underlying claim.

The question presented in China Agritech, Inc. v. Resh ${ }^{208}$ was whether the members of a failed class could file a subsequent class action, as opposed to an individual suit, if that class action would otherwise be barred by the statute of limitations. In other words, the question was whether the principle of equitable tolling would permit the filing of successive and otherwise barred class actions once class certification is denied in the initial tolling proceeding. The Court held that the principle did not permit filing under those circumstances. ${ }^{209}$

In so holding, the Court employed what one might call a partial dueprocess analysis, focusing exclusively on the efficiency component of the principle. In the Court's words,

The "efficiency and economy of litigation" that support tolling of individual claims, do not support maintenance of untimely successive class actions; any additional class filings should be made early on,

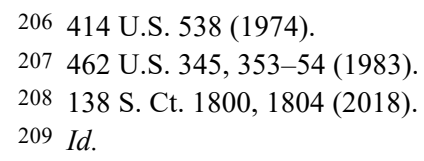


soon after the commencement of the first action seeking class certification.

American Pipe tolls the limitation period for individual claims because economy of litigation favors delaying those claims until after a class-certification denial. If certification is granted, the claims will proceed as a class and there would be no need for the assertion of any claim individually. If certification is denied, only then would it be necessary to pursue claims individually.

With class claims, on the other hand, efficiency favors early assertion of competing class representative claims. If class treatment is appropriate, and all would-be representatives have come forward, the district court can select the best plaintiff with knowledge of the full array of potential class representatives and class counsel. And if the class mechanism is not a viable option for the claims, the decision denying certification will be made at the outset of the case, litigated once for all would-be class representatives. ${ }^{210}$

In support of this assessment, the Court cited recent amendments to Rule 23(c) that endorse the efficiency rationale. ${ }^{211}$

On a superficial level, the Court's decision feels right. But in a concurring opinion, Justice Sotomayor convincingly argues that the Court may have overplayed the efficiency rationale to the detriment of fairness. To that end, she proposes a more limited standard:
Instead of adopting a blanket no-tolling-of-class-claims-ever rule . . . the Court might hold, as a matter of equity, that tolling only becomes unavailable for future class claims where class certification is denied for a reason that bears on the suitability of the claims for class treatment. Where, by contrast, class certification is denied because of the deficiencies of the lead plaintiff as class representative, or because of some other nonsubstantive defect, tolling would remain available. ${ }^{212}$

The driving force behind this alternative standard is fairness to the putative class members. As Justice Sotomayor sees it, the Court's approach may well lead to the filing of multiple parallel class actions with the potential adverse consequence of a strategic drive to the bottom in settlement negotiations:

[T] he existence of multiple putative class actions covering the same harm to the same class may lead to a "race toward judgment or settlement." Each class lawyer knows that only the lawyers in the first-resolved case will get paid, because the other suits will then be dismissed on claim-preclusion grounds. Defense lawyers know this,

\footnotetext{
210 Id. at $1806-07$ (citation omitted).

211 Id. at 1807.

212 Id. at 1814 (Sotomayor, J., concurring).
} 
too, so they are 'able to engage in a 'reverse auction,' pitting the various class counsel against one another and agreeing to settle with the lawyer willing to accept the lowest bid on behalf of the class." This gamesmanship is not in class members' interest, nor in the interest of justice. ${ }^{213}$

If, as we have asserted, the aim of due process is justice reasonably, fairly, and efficiently pursued, then the majority's obeisance to efficiency falls one step short of the idea of due process by failing to account for the potential unfairness of its across-the-board standard. We might say it's easy to apply but difficult to justify as a matter of complete due process. Surely Justice Sotomayor was attempting to correct that unfairness. But at the very least, the Court should have adopted a standard that contemplated the potential unfairness of denying equitable tolling in contexts not precisely covered by the case pending before it, such as those noted by Justice Sotomayor.

\section{CONCLUSION}

The goal of this Article is to reboot the law of class actions with the aim of allowing Rule 23 to reach its full potential as a tool of collective dispute resolution consistent with due process. The idea of due process is a promise of adherence to the rule of law tempered by reasonableness, fairness, and efficiency. It embraces both the value of individual autonomy and the collective interests of the community. The idea of class actions, premised on due process, is to provide a pragmatic method of dispute resolution that is fair to the individual and responsive to the needs of the community and the challenges generated by widely spread and shared harms. In this respect, class actions operate as a tool of democracy. Rule 23 should be interpreted from this hopeful and effective perspective - one that balances individual autonomy against the legitimate needs of the community. Instead, the Rule appears to be infused with its framers' self-doubts and the Supreme Court's treatment of it as an unwelcome guest in the home of traditional litigation forms. We hope that our analysis will provide helpful insight for a reformed interpretation and application of Rule 23 that will allow it to fulfill its democratic function.

213 Id. at 1814-15 (citing Rhonda Wasserman, Dueling Class Actions, 80 B.U. L. REV. $461(2000))$. 